MONIKA WAŁACHOWSKA

https://doi.org/10.33995/wu2021.3.5

\title{
Koszty nieodpłatnej opieki nad poszkodowanym a zakres odpowiedzialności ubezpieczyciela za szkodę na osobie. Uwagi na tle uchwały 7 sędziów Sądu Najwyższego z 22 lipca 2020 roku [sygn. III CZP 31/19]
}

W niniejszym opracowaniu dokonano analizy stanowiska Sqdu Najwyższego, zgodnie z którym koszty nieodpłatnej opieki sprawowanej nad poszkodowanym mieszcza się pojęciu kosztów wynikłych z doznania szkody na osobie. Autorka wskazuje na rozmaite stanowiska zajmowane przez sqdy i doktrynę, dowodzqc, że poglad SN można co do zasady podzielić. Dodaje, że istnieja również argumenty przemawiajqce za tym, że fakt konieczności korzystania z pomocy osób trzecich nie tylko może być w konkretnej sprawie uznany za uszczerbek o charakterze majatkowym, ale także jako czynnik brany pod uwage przy szacowaniu szkody niemajatkowej.

Słowa kluczowe: szkoda na osobie, koszty leczenia, nieodpłatna opieka, odszkodowanie, zadośćuczynienie.

\section{Wstęp. Pytanie prawne Rzecznika Finansowego}

Na podstawie art. 83 § 1-2 ustawy z 8 grudnia 2017 roku o Sadzie Najwyższym (Dz. U. 2018, poz. 5) Rzecznik Finansowy skierował 29 kwietnia 2019 roku wniosek (RF/19/TML/ALD ${ }^{1}$ ) o podjęcie uchwały mającej na celu rozstrzygnięcie istniejacych w orzecznictwie sądów rozbieżności co do wykładni prawa w odniesieniu do zasadności odszkodowania z tytułu kosztów nieodpłatnej opieki sprawowanej nad poszkodowanym przez osoby bliskie. Rzecznik zwrócił się o odpowiedź

1. Treść dostępna na stronie https://rf.gov.pl/wp-content/uploads/2020/05/Wniosek-RF_SN_rekomensata_za_ opieke_2019.pdf [dostęp: 6.09.2021]. 
na następujące pytanie: „Czy poszkodowanemu, który doznał uszkodzenia ciała lub rozstroju zdrowia, przysługuje na podstawie art. 444 § 1 k.c. odszkodowanie z tytułu kosztów opieki sprawowanej nad nim nieodpłatnie przez osoby bliskie?"

Rzecznik zwrócił uwagę, że w orzecznictwie sądowym dają się zauważyć istotne rozbieżności w zakresie wykładni art. 444 § 1 k.c. oraz co do interpretacji pojęcia wszelkich kosztów wynikłych z uszkodzenia ciała lub wywołania rozstroju zdrowia w kontekście sprawowania nieodpłatnej opieki nad poszkodowanym, której to często podejmują się osoby bliskie poszkodowanego, kierując się troską o poszkodowanego i o jego dobrostan psychiczny, a czemu nierzadko towarzyszy brak środków na zatrudnienie opiekuna. Rzecznik zwrócił uwagę, że pytanie nie dotyczy sytuacji, w której osoby bliskie poszkodowanego zrezygnowały z wykonywania pracy zarobkowej czy prowadzenia działalności gospodarczej lub zawodowej, czy też ograniczyły ich wymiar, a zatem nie doszło do utraty dochodów, ale w celu sprawowania opieki poświeciły swój czas, ponosząc określony wysiłek w celu pielęgnacji poszkodowanego, udzielania mu pomocy w bieżących sprawach dnia codziennego, dowożenia na wizyty lekarskie czy rehabilitację, robienia zakupów itp. Zdaniem Rzecznika taką nieodpłatna pomoc wykonują nierzadko choćby osoby bezrobotne, emeryci, studenci, pracownicy wykorzystujacy urlop wypoczynkowy czy osoby podejmujace się opieki po pracy lub w dniach od niej wolnych.

Jak zwrócił uwagę Rzecznik, konieczność rozstrzygnięcia sprawy wynika z faktu, że w orzecznictwie da się zauważyć różną kwalifikację owej opieki i - w konsekwencji - różne przepisy są podstawą orzekania w tego typu sprawach. Jednocześnie wskazano, że w wielu sprawach zobowiązani do wypłaty odszkodowania z tego tytułu mogą być ubezpieczyciele w związku z zawarciem przez podmiot odpowiedzialny umowy ubezpieczenia odpowiedzialności cywilnej (tak o charakterze obowiazkowym, jak i dobrowolnym].

W omawianym wniosku Rzecznik wskazał przede wszystkim na orzeczenia, w których zarysowała się odmienna wykładnia art. 444 § 1 k.c., zgodnie z którym „w razie uszkodzenia ciała lub wywołania rozstroju zdrowia naprawienie szkody obejmuje wszelkie wynikłe z tego powodu koszty. Na żądanie poszkodowanego zobowiązany do naprawienia szkody powinien wyłożyć z góry sumę potrzebną na koszty leczenia, a jeżeli poszkodowany stał się inwalidą, także sumę potrzebna na koszty przygotowania do innego zawodu”. Ponadto w części powołanych we wniosku orzeczeń zastosowano art. 444 § 2 k.c., zgodnie z którym ,jeżeli poszkodowany utracił całkowicie lub częściowo zdolność do pracy zarobkowej albo jeżeli zwiększyły się jego potrzeby lub zmniejszyły widoki powodzenia na przyszłość, może on żądać od zobowiązanego do naprawienia szkody odpowiedniej renty". Wreszcie w innych rozstrzygnięciach powoływano odmienne argumenty, które stawały się podstawą do zasądzenia renty skapitalizowanej za okres przeszły bądź uzależniały przyznanie odszkodowania od dodatkowych okoliczności.

Rzecznik wskazał, że w pierwszej grupie spraw² uznawano jako zasadę, że konieczność sprawowania nieodpłatnej opieki przez osobę bliską poszkodowanego mieści się w pojęciu wszelkich kosztów będących skutkiem wyrządzenia szkody na osobie. Najczęściej szacowanie rozmiaru

2. Zob. zwłaszcza wyrok SA w Warszawie z 7.03.2013 r., sygn. VI ACa 1266/12; wyrok SA w Gdańsku z 20.08.2013 r., sygn. V ACa 388/13; wyrok SA w Warszawie z 1.10.2013 r., sygn. VI ACa 40/13; wyrok SA w Katowicach z 27.01.2015 r., sygn. I ACa 637/14; wyrok SA w Łodzi z 25.06.2015 r., sygn. I ACa 104/15; wyrok SA w Krakowie z 20.10.2015 r., sygn. I ACa 911/15; wyrok SA w Warszawie z 16.02.2016 r., sygn. VI ACa 863/15; wyrok S0 w Białymstoku z 23.03.2017 r., sygn. II Ca 31/17; wyrok SA w Warszawie z 22.02.2018 r., sygn. I ACa 1963/16. 
tego uszczerbku odbywało się poprzez odwołanie się do cen rynkowych tzw. roboczogodziny, a więc stawki na lokalnym rynku, dzięki której możliwe jest zatrudnienie profesjonalnego opiekuna (odwoływano się najczęściej do stawek usług opiekuńczych i specjalistycznych oraz art. 322 k.p.c.). Wspólny w tych sprawach był także argument, że szkoda jest sama konieczność korzystania z opieki, znaczenia nie ma natomiast, czy opiekę tę sprawują nieodpłatnie członkowie rodziny. Sądy uznały zatem, że nawet jeśli poszkodowany nie poniósł określonych wydatków, to sam fakt konieczności korzystania z pomocy osób trzecich stanowi uszczerbek, który ma wymierną wartość majątkowa. Nie ma przy tym znaczenia, czy poszkodowany te koszty rzeczywiście poniesie, czy też opiekę nad nim będzie sprawować nieodpłatnie osoba bliska, sama bowiem konieczność skorzystania z pomocy stanowi o zwiększeniu się potrzeb poszkodowanego, których zaspokojenie ma realną wartość majątkowa ${ }^{3}$. Odszkodowanie z tego tytułu uzależnione jest jednocześnie od wykazania, czy faktycznie z uwagi na stan zdrowia poszkodowany takiej opieki potrzebował.

W drugiej grupie spraw powołanych przez Rzecznika sądy zwracały uwagę, że odszkodowanie na podstawie art. $444 \S 1$ k.c. może być zasadne jedynie wówczas, gdy poszkodowany wykaże fakt poniesienia kosztów sprawowania opieki przez osoby trzecie ${ }^{4}$. Innymi słowy roszczenie o odszkodowanie traktuje się w tych sprawach jako przeciwstawne roszczeniu o rentę z tytułu zwiększonych potrzeb, przy którego dochodzeniu nie wymaga się wykazania poniesionych wydatków, ale samego faktu istnienia zwiększonych potrzeb w związku ze szkodą na osobie wyrządzoną wskutek czynu niedozwolonego. Sądy uznawały w związku z tym, że odszkodowanie byłoby zasadne tylko wówczas, gdyby np. mąż poszkodowanej wykazał, że korzystał ze zwolnień z pracy czy urlopu bezpłatnego w celu sprawowania opieki, albo powódka poniosła koszty opieki sprawowanej przez osoby trzecie ${ }^{5}$. W tych sprawach uznano zatem, że szkoda jest dopiero poniesiony wydatek ${ }^{6}$, dokładnie udokumentowany, którego konieczność została wykazana, sama zaś konieczność korzystania z opieki może uzasadniać przyznanie renty z tytułu zwiększonych potrzeb.

Wreszcie Rzecznik wskazał na orzeczenia, w których sądy odwoływały się jeszcze do innych argumentów. Przykładowo wskazywano, że konieczność korzystania z opieki osoby trzeciej nad powodem należy zaliczyć do zwiększonych potrzeb, znaczenia nie ma natomiast, na jaką podstawę prawną powołuje się powód? Niekiedy uznawano, że odszkodowanie na podstawie art. 444 § 1 k.c. może być zasadne w razie wykazania faktycznie poniesionych wydatków (zwłaszcza w razie zatrudnienia opiekuna albo np. gdy doszło do utraty korzyści przez członków rodziny w związku

3. Tak też wyrok SA w Katowicach z 19.01.2018 r., sygn. I ACa 812/17. Sąd jednocześnie uznał, że wartość tej opieki może podlegać kompensacji zarówno w oparciu o art. 444 § 1 (gdy poszkodowany już z opieki korzystał), jak i art. $444 \S 2$ k.c. (gdy opieki tej będzie nadal wymagał w przyszłości). Podobnie - wyrok SA w Warszawie z 22.02.2018 r., sygn. I ACa 1963/16.

4. Zob. m.in. wyrok SA w Lublinie z 24.04.2013 r., sygn. I ACa 59/13; wyrok SA w Białymstoku z 5.03.2014 r., sygn. I ACa 804/13; wyrok SA w Katowicach z 14.08.2014 r., sygn. I ACa 362/14; wyrok SO w Lublinie z 28.05.2015 r., sygn. I C 487/13; wyrok SA w Białymstoku z 13.05.2015 r., sygn. I ACa 32/15.

5. Tak wyrok SA w Katowicach z 14.08.2014 r., sygn. I ACa 362/14; zob. też wyrok SA w Gdańsku z 26.09.2014 r., sygn. VACa 480/14.

6. Tak np. wyrok SO w Kaliszu z 5.04.2018 r., sygn. II CA 633/17. Zdaniem sądu chodzi o realnie poniesione wydatki, a także np. wysokość dochodu utraconego przez osobę świadcząca poszkodowanemu nieodpłatnie opiekę i pomoc, która w tym celu musiała np. ograniczyć pracę zarobkową. W ocenie sądu poszkodowany, zgodnie z art. 6 k.c., powinien wykazać fakt poniesienia wydatków, a nie samą konieczność ich poniesienia.

7. Zob. wyrok SA w Lublinie z 15.04.2014 r., sygn. I ACa 685/13. 
z ograniczeniem, a nawet zaprzestaniem aktywności zarobkowej, rezygnacji z urlopu], zaś w razie wykazania konieczności opieki oraz jej faktycznego wykonywania powodowi należy się z tego tytułu skapitalizowana renta (art. $444 \S 2$ k.c.) ${ }^{8}$. W sprawach tych doszło zatem do wyraźnego odróżnienia odszkodowania od renty z tytułu zwiększonych potrzeb.

\section{Dotychczasowe orzecznictwo Sądu Najwyższego}

Jeśli chodzi o orzecznictwo Sądu Najwyższego dotyczące zasadności roszczenia o zwrot kosztów opieki, skupiało się ono na analizie przesłanek zawartych w art. 444 § 2 k.c., zaś argumenty SN były powoływane przez sądy powszechne, co jednak prowadziło niejednokrotnie do odmiennych wniosków. W wyroku z 4 marca 1969 roku (sygn. I PR 28/69] SN stwierdził, że prawo poszkodowanego do ekwiwalentu z tytułu zwiększonych potrzeb, polegających na konieczności korzystania z opieki osoby trzeciej, nie jest uzależnione do wykazania faktycznie poniesionych w tym celu wydatków ${ }^{9}$. Prawa do otrzymania renty nie pozbawia fakt, że poszkodowany pozostawał na utrzymaniu rodziny, ani że opiekę sprawowali właśnie członkowie rodziny. Zatem samo istnienie potrzeby opieki uzasadnia żądanie renty ${ }^{10}$. Jeśli natomiast współmałżonek poszkodowanego ograniczył wykonywanie pracy zarobkowej, różnica w dochodach mieści się w pojęciu wszelkich kosztów, o których mowa w art. 444 § 1 k.c. Jeśli jednak opieka może być sprawowana przez osobę trzecią, wysokość odszkodowania z tego tytułu nie może przewyższać wynagrodzenia osoby mającej odpowiednie kwalifikacje do wykonywania czynności opieki ${ }^{11}$.

\section{Uchwała Sądu Najwyższego - Izby Cywilnej (sygn. III CZP 31/19)}

W dniu 22 lipca 2020 roku Sąd Najwyższy podjął uchwałę w składzie ? sędziów ${ }^{12}$, w której orzekł, że „poszkodowany, który doznał uszkodzenia ciała lub rozstroju zdrowia, może domagać się na podstawie art. $444 \S 1$ k.c. odszkodowania z tytułu kosztów opieki sprawowanej nad nim nieodpłatnie przez osoby bliskie". Sąd Najwyższy wskazał, że generalnie dotąd nie budziła wąpliwości możliwość dochodzenia renty z tytułu zwiększonych potrzeb w razie, gdy poszkodowany wskutek czynu niedozwolonego wymagał pomocy i opieki sprawowanej przez osoby trzecie (zarówno odpłatnie, jak i nieodpłatnie) ${ }^{13}$. Rzadziej natomiast wypowiadano się na temat kosztów opieki sprawowanej przez osoby bliskie, w takich sytuacjach analizowano jedynie realny uszczerbek majątkowy, jaki powstawał po stronie osób bliskich, co miało w szczególności postać utraty

8. Tak wyrok SO w Piotrkowie Trybunalskim z 4.09.2014 r., sygn. I C 967/12.

9. Tak też wyrok SN z 11.03.1976 r., sygn. IV CR 50/76; wyrok SN z 26.07.1977 r., sygn. I CR 143/77.

10. Tak wyrok SN z 28.11.1972 r., sygn. I CR 534/72; wyrok SN z 22.05.2005 r., sygn. III CK 392/04; wyrok SN z 8.02.2012 r., sygn. V CSK 57/11.

11. Tak wyrok SN z 4.10.1973 r., sygn. II CR 365/73; zob. też wyrok SN z 15.02.2007 r., sygn. II CSK 474/06.

12. Nie ma ona jednak mocy zasady prawnej.

13. Zob. np. wyroki SN z 4.03.1969 r., sygn. I PR 28/69; z 28.11.1972 r., sygn. I CR 534/72; z 26.071977 r., sygn. I CR 143/77; z 8.02.2012 r., sygn. V CSK 57/11. 
wynagrodzenia wskutek zaprzestania pracy zarobkowej ${ }^{14}$ czy zawieszenia działalności gospodarczej ${ }^{15}$. W takich sprawach SN uznawał, że doznany w ten sposób uszczerbek stanowi szkodę pozostająca w adekwatnym związku przyczynowym ze zdarzeniem i podlega wynagrodzeniu na podstawie art. $444 \S 1$ k.c. Odszkodowanie to nie mogło być jednak wyższe niż rynkowa wartość sprawowanej opieki, a więc wynagrodzenia osoby posiadającej odpowiednie kwalifikacje. Warto dodać, że w omawianej uchwale SN odwołał się do uchwały ? sędziów SN z 19 maja 2016 roku (sygn. III CZP 63/15), w której przyjęto, że określenie „wszelkie koszty” zawarte w treści art. $444 \S 1$ k.c. obejmuje m.in. koszty leczenia i rehabilitacji, zatem pojęcie tych kosztów może dotyczyć zarówno kosztów już poniesionych, jak i tych, których poniesienie może być przydatne w przyszłości (zob. też art. $444 \S 1$ zd. 2 k.c. dotyczący roszczenia o wyłożenie z góry sumy potrzebnej na pokrycie kosztów leczenia). Podkreślono, że w każdym przypadku poszkodowany powinien wykazać, że pewne koszty (już poniesione lub przyszłe) są celowe i niezbędne, oraz że pozostaja w normalnym związku przyczynowym ze zdarzeniem.

Sąd odwołał się także to wyroku SN z 17 lipca 2019 roku ( I PK 17/19), w którym uznano, że sprawowanie opieki przez żonę nieodpłatnie nie uchyla obowiązku pokrycia szkody w tym zakresie. Podkreślono wówczas, że oceniając zasadność roszczenia o odszkodowanie, opiekę świadczoną przez osoby najbliższe należy traktować tak samo, jak opiekę sprawowaną odpłatnie przez osoby obce (np. pielęgniarkę przychodzącą na kilka godzin). Korzystanie z pomocy innej osoby i związane z tym koszty stanowią zatem koszty leczenia w rozumieniu art. 444 § 1 k.c. Sąd Najwyższy w głosowanej uchwale zauważyłjednak, że cytowany wyrok I PK 17/19 - o ile zalicza wartość opieki do odszkodowania z art. 444 § 1 k.c., o tyle w uzasadnieniu odwołuje się w istocie do orzecznictwa uzasadniającego możliwość wynagrodzenia szkody w oparciu o rentę z art. 444 § 2 k.c. Z kolei w wyroku z 31 stycznia 2019 roku (sygn. V CSK 599/17) uznano, że koszty opieki sprawowanej przez osoby bliskie moga podlegać kompensacji na podstawie art. $444 \S 1$ k.c., pod warunkiem że poszkodowany wykaże, że rzeczywiście poniósł związane z tym wydatki. 0 ile zatem dotychczasowe orzecznictwo nie było jednolite w odniesieniu do wykładni pojęcia szkody (ujmowanej bądź jako przesłanka obowiązku odszkodowawczego w związku z samym powstaniem konieczności zapewnienia poszkodowanemu opieki, bądź jako poniesione już wydatki z tym związane), o tyle glosowana uchwała oparta jest na założeniu, że pojęcie wszelkich kosztów powinno być rozumiane w ten sposób, że obejmuje także konieczność ich poniesienia (i to nawet nie w sensie dosłownym, skoro mowa o szacowaniu realnej wartości opieki sprawowanej nieodpłatnie), a nie tylko wydatki realnie już poniesione (w tym drugim przypadku wręcz musiałoby to - moim zdaniem - prowadzić do oddalenia powództwa, skoro opieka sprawowana była nieodpłatnie).

\section{Ocena stanowiska Sądu Najwyższego}

Zanim przejdę do oceny tytułowej uchwały, warto odnieść się do poglądów doktryny w przedmiocie kompensacji kosztów opieki sprawowanej nad poszkodowanym. Wydaje się, że odmienne poglądy wiążą się z samym rozumieniem momentu powstania obowiązku odszkodowawczego (inną kwestiąjest natomiast wykładnia pojęcia wszelkich kosztów z art. $444 \S 1$ k.c.). Po pierwsze, twierdzi

14. Tak wyrok SN z 4.10.1973 r., sygn. II CR 365/73.

15. Wyrok SN z 15.02.2007 r., sygn. II CSK 474/06. 
się, że obowiązek odszkodowawczy powstaje już w chwili, gdy wskutek doznania szkody na osobie powstaje konieczność ${ }^{16}$ zapewnienia poszkodowanemu opieki. Zatem przesłanką wystapienia z żądaniem nie jest faktycznie poniesienie określonych kosztów, ale sama konieczność ich poniesienia. Wiąże się to z faktem, że opieka jako taka i pomoc w bieżących sprawach mają określoną wartość majątkową ${ }^{17}$. Innymi słowy: fakt ponoszenia całego ciężaru opieki na poszkodowanym w czasie leczenia i rehabilitacji przez członków rodziny nie zwalnia osoby odpowiedzialnej od zwrotu kwoty obejmującej wartość tych świadczen ${ }^{18}$. Zatem w takim przypadku należałoby w celu ustalenia wartości tej opieki odwołać się do kosztów wynagrodzenia osoby mającej odpowiednie kwalifikacje do wykonywania niezbędnych czynności ${ }^{19}$.

Po drugie, można twierdzić, że roszczenie o odszkodowanie jest zasadne tylko wówczas, gdy faktycznie doszło do poniesienia określonych wydatków ${ }^{20}$ lub ze sprawowaniem opieki wiąże się jakiś konkretny uszczerbek majątkowy (wynikający np. z ograniczenia działalności gospodarczej czy zawodowej). Nie wystarczy zatem sama potrzeba poniesienia kosztów (jak w związku z żądaniem renty z tytułu zwiększonych potrzeb na podstawie art. $444 \S 2$ k.c.), ale wymagane jest ich poniesienie ${ }^{21}$ i udowodnienie ich wysokości. Jest to jednocześnie wyrazem koncepcji szkody nie jako samego naruszenia, ale skutku tego naruszenia ${ }^{22}$.

Biorąc pod uwagę brak jednolitości w orzecznictwie oraz rozbieżność poglądów w nauce prawa, Sąd Najwyższy trafnie uznał, że centralnym pojęciem, które wymaga analizy, jest przesłanka szkody, jako jednego z podstawowych elementów każdego stosunku odszkodowawczego. Sąd odwołał

16. Zob. też - odnośnie koncepcji szkody jako naruszenia i szkody jako skutku naruszenia - E. Bagińska, [w:] System Prawa Medycznego. Tom 5. Odpowiedzialność prywatnoprawna, [red.] E. Bagińska, CH Beck, Warszawa 2021, s. 681-682.

17. Zob. też M. Safjan, [w:] Kodeks cywilny. Tom I. Komentarz. Art. 1-449[10], [red.] K. Pietrzykowski, CH Beck, Warszawa 2015, s. 1499, nb 8; P. Sobolewski, [w:] Kodeks cywilny. Komentarz, red. K. Osajda, wyd. 28, CH Beck, Warszawa 2021, Legalis (kom. do art. 444 k.c., pkt B.5 [koszty opieki]).

18. Tak wyrok SN z 4.03.1969 r., sygn. I PR 28/69; wyrok SN z 4.10.1973 r., sygn. II CR 365/73; wyrok SN z 8.02.2012 r., sygn. V CSK $57 / 11$.

19. Tak wyrok SA w Warszawie z 7.03.2013 r., sygn. VI ACa 1266/12.

20. Zob. też M. Kaliński, Szkoda na mieniu i jej naprawienie, CH Beck, Warszawa 2014, s. 56 i nast.; R. Strugała, Dobra i interesy chronione w strukturze czynu niedozwolonego, CH Beck, Warszawa 2019, s. 11-14; J. Misztal-Konecka, Kilka uwag o kosztach opieki nad poszkodowanym jako szkodzie podlegajqcej naprawieniu na podstawie art. $444 \S 1$ zd. 1 k.c., [w:] lus est iustitia appelatum. Księga jubileuszowa dedykowana Profesorowi Tadeuszowi Wiśniewskiemu, [red.] T. Ereciński, J. Gudowski, M. Pazdan, M. Tomalak, Wolters Kluwer, Warszawa 2017, s. 884; W. Czachórski, [w:] System Prawa Cywilnego. Tom III. Część 1. Prawo zobowiqzań - część ogólna, [red.] Z. Radwański, Ossolineum, Wrocław 1981, s. 663-664; P. Machnikowski, A. Śmieja, [w:] System Prawa Prywatnego. Tom 6. Prawo zobowiqzań - część ogólna, [red.] A. Olejniczak, CH Beck, Warszawa 2018, s. 739.

21. Zob. też S. Hadrowicz, Nieodpłatna opieka jako koszt w świetle art. 444 § 1 k.c., „Studia Prawa Prywatnego” 2021, nr 2, s. 55. Zdaniem Autorki nieodpłatna opieka w ogóle nie jest „kosztem” w świetle art. 444 § 1 k.c. zob. eadem, Koszty „nieodpłatnej” opieki a pojęcia szkody podlegajacej kompensacji na podstawie art. 444 $\S 1$ k.c. Glosa do uchwały składu siedmiu sędziów Sqdu Najwyższego - Izba Cywilna z dnia 22 lipca 2020 r., III CZP 31/19, „Orzecznictwo Sądów Polskich” 2021, nr 6, poz. 45, s. 46.

22. Zob. też M. Kaliński, Szkoda na osobie i jej naprawienie, CH Beck, Warszawa 2021, s. 34 i cytowana tam literatura. Autor, odwołując się do metody obiektywnej oceny szkody, twierdzi jednocześnie, że jeśli pomoc była świadczona nieodpłatnie, nie ma w ogóle podstaw do wypłaty odszkodowania, gdyż byłby to swego rodzaju ryczałt pozwalający na obejście braku uszczerbku - ibidem, s. 98. Pogląd ten uważam za zbyt daleko idący, zwłaszcza, że wartość opieki i związanych z nią czynności może zostać w sposób obiektywny oszacowana. 
się przede wszystkim do art. 361 k.c. oraz metody dyferencyjnej, do której nawiązuje zwłaszcza ten nurt w orzecznictwie, w którym odrzuca się możliwość dochodzenia odszkodowania w związku ze sprawowaniem nieodpłatnej opieki. Wskazuje się, że odwołanie się do teorii różnicy prowadzi do wniosku, że w majątku osoby poszkodowanej nie powstaje uszczerbek. W uchwale III CZP 31/19 podkreślono, że takie stanowisko budzi zastrzeżenia i nie sposób się z nim zgodzić. Sad, odwołując się do pojęcia wszelkich kosztów z art. 444 § 1 k.c. i szczególnego charakteru przepisów o sposobach wynagrodzenia szkody na osobie, wskazał, że samo rozumienie pojęcia kosztów nie może być utożsamiane wyłącznie z konkretnymi wydatkami (już poniesionymi), ale winno obejmować także wartość czegoś. Z pewnością zatem art. 444 § 1 k.c. nie może być rozumiany w ten sposób, że obejmuje odszkodowanie wyłącznie za już poniesione wydatki, które można udokumentować. Zdaniem SN, skoro cytowany przepis dotyczy „kosztów” a nie „wydatków”, to chodzi w nim także o możliwość kompensacji równowartości kosztów, których poniesienie jest zasadne w związku z doznaną szkodą na osobie.

Sad Najwyższy podkreślił, że sama konieczność korzystania z opieki stanowi szczególnego rodzaju uszczerbek, zwiększający potrzeby osoby poszkodowanej, które wchodzą w skład kosztów leczenia z art. 444 § 1 k.c. Uznał, że „opieka ta ma obiektywnie wymierną wartość ekonomiczną nawet wtedy, gdy była sprawowana nieodpłatnie". Dzięki takiemu rozumieniu wszelkich kosztów poszkodowany może dochodzić odszkodowania niezależnie od tego, kto i w jaki sposób naprawił szkodę $^{23}$. Dodatkowo SN podkreślił, że taka wykładnia jest szczególnie uzasadniona w sprawach, w których wykazano, że z nieodpłatnej opieki osób bliskich korzystają osoby niezamożne, nieposiadające środków na wynagrodzenie profesjonalisty (np. pielęgniarki). Gdyby było inaczej, odmiennie kształtowałaby się sytuacja osób zamożniejszych, które byłyby w stanie udokumentować fakt zatrudnienia opiekuna, oraz osób mniej zamożnych, które z braku środków zmuszone były korzystać z pomocy np. członków najbliższej rodziny ${ }^{24}$. Pomoc świadczona dobrowolnie przez osoby bliskie nie może ponadto zmniejszać obowiązku odszkodowawczego podmiotu zobowiązanego ${ }^{25}$. Gdyby przyjąć odmienne wnioskowanie, dochodziłoby, zdaniem SN, do zawierania fikcyjnych odpłatnych umów między np. małżonkami, co miałoby na celu wykazanie poniesienia określonych wydatków. Na koniec SN orzekł, że nie ma przekonujących argumentów pozwalających uznać, że koszty nieodpłatnej opieki (sprawowanej w przeszłości) mogą uzasadniać tylko przyznanie renty na podstawie art. $444 \S 2$ k.c., nie stanowią natomiast składnika odszkodowania, którego dotyczy art. 444 § 1 k.c. SN uznał, że zarówno wykładnia językowa, systemowa, jak i celowościowa

23. Podobnie jest choćby w przypadku kosztów dojazdu osób bliskich poszkodowanego do szpitala czy kosztów specjalnej diety - może chodzić o wydatki już poniesione, ale także takie, których ponoszenie w przyszłości może mieć miejsce.

24. Czasem natomiast może, moim zdaniem, chodzić także o przesłanki innej natury, nie tylko finansowe - można sobie przecież wyobrazić sytuację, że w miejscu zamieszkania poszkodowanego brak dostępnych form odpłatnej opieki. Ponadto nierzadko przecież osoby bliskie sprawują opiekę bez obowiązku ustawowego, ale po prostu z potrzeby pomocy (np. pełnoletnie rodzeństwo poszkodowanego czyni to w czasie urlopu wypoczynkowego "kosztem" własnego czasu wolnego).

25. Podobne stanowisko byłoby, moim zdaniem, zasadne przy ocenie innych świadczeń pochodzących od osób trzecich, które dobrowolnie ponoszą pewne wydatki związane z pomoca poszkodowanemu - nie mogłaby tu mieć zastosowania zasada compensatio lucri cum damno (wartość tych świadczeń, opieki itp. nie może być uznana za korzyść, której wartość zmniejszałaby zakres obowiązku odszkodowawczego). 
prowadzą do wniosku, że art. 444 § 1 k.c. może stanowić podstawę zasądzenia odszkodowania obejmującego wartość opieki nad poszkodowanym, sprawowanej nieodpłatnie przez osoby bliskie.

Sądzę, że uchwałę SN należy rozumieć w ten sposób, że w istocie SN stanął na stanowisku, że obowiązek odszkodowawczy powstaje już wówczas, gdy u poszkodowanego pojawia się potrzeba opieki, zaś jej wartość da się obiektywnie wycenić na podstawie kryteriów rynkowych. Warunkiem jest wykazanie, że opieka ta była faktycznie celowa i konieczna (także np. pod względem czasowym ], a więc tak, jak to podkreślono w uchwale III CZP 63/15. Dzięki temu możliwa jest nie tylko spójna interpretacja adekwatnego związku przyczynowego w tego typu sprawach, ale także szeroka wykładnia pojęcia wszelkich kosztów.

Wnioski płynące z uchwały SN są niewątpliwie daleko idące także dla ubezpieczycieli, których odpowiedzialność ma charakter akcesoryjny, istnieje w granicach odpowiedzialności podmiotu, którego odpowiedzialność jest objęta umową ubezpieczenia OC. Po pierwsze, sąd przyjał szeroką wykładnię pojęcia szkody wynikłej z uszkodzenia ciała lub wywołania rozstroju zdrowia, wskazując, że obowiązek odszkodowawczy powstaje już z chwila konieczności korzystania z opieki przez poszkodowanego. Innymi słowy: nie jest konieczne wykazanie poniesienia konkretnych wydatków z tym związanych, ale wystarczy fakt, że konieczność skorzystania z opieki osoby trzeciej w ogóle powstała ${ }^{26}$. Po drugie, przyjęta wykładnia harmonizuje z ogólnymi zasadami ustalania odszkodowania, a zwłaszcza z zasada, że nie jest istotne, kto i w jaki sposób naprawił szkodę. Po trzecie, uchwała nie wprowadza jakiegoś „standardu odszkodowawczego”. Rozumieć ją raczej należy w ten sposób, że zasadność tego typu roszczenia będzie musiała być poddawana ocenie ad casum, uwzględniać okoliczności każdego przypadku ( a więc przede wszystkim to, czy faktycznie celowe było sprawowanie opieki w danej postaci i wymiarze, jak to przedstawia powód). Nie można zatem odejść od zasady indywidualizacji odszkodowania. Jednocześnie SN nie przesądził, w jaki sposób ma przebiegać szacowanie wartości opieki sprawowanej nieodpłatnie przez osoby bliskie poszkodowanego. Nie zawsze zatem, jak się wydaje, adekwatne będzie wprost odwoływanie się do stawek godzinowych, właściwych np. dla opiekunek zawodowo trudniących się tego typu działalnością 27 , choć wydaje się to regułą (co sprzyja jednolitości rozstrzygnięć oraz realizuje zasadę obiektywnej oceny wielkości uszczerbku i należnego odszkodowania). Moim zdaniem należy raczej przyjąć, że zgodnie z ogólną zasadą ciężaru dowodu (art. 6 k.c.), poszkodowany będzie musiał wykazać nie tylko konieczność korzystania z pomocy innych osób, ale także zasadność np. określonej liczby godzin dziennie czy wykonywania pewnych czynności w ogóle. Nie zawsze przecież, zwłaszcza gdy charakter i rozmiar doznanej szkody na osobie za tym nie przemawia, konieczna jest np. rezygnacja z wszystkich własnych zajęć wykonywanych w czasie wolnym, przerwa w studiowaniu, treningach, rezygnacja z życia towarzyskiego przez osoby trzecie. W każdym przypadku nie tylko sama zasadność korzystania z nieodpłatnej opieki, ale także jej wymiar i rzeczywista wartość będą podlegały ocenie sądu. Pomocne może być niewątpliwie sięgnięcie do art. 322 k.p.c. (trudno przecież precyzyjnie wycenić wartość czasu wolnego poświęconego na pomoc osobie bliskiej choćby w zrobieniu zakupów, higienie, zmianie opatrunków, opiece nad

26. Również SA w Łodzi w wyroku z 11.06.2014 r., sygn. I ACa 1593/13 orzekł, że to, że opiekę zapewniali poszkodowanemu członkowie rodziny, nie zaś profesjonalny personel medyczny, nie może prowadzić do wyłaczenia lub ograniczenia jego prawa do odszkodowania z tego tytułu.

27. Zob. wyrok SA w Białymstoku z 19.06.2019 r., sygn. I ACa 816/18. 
dziećmi czy polegającej po prostu na udzielaniu psychicznego wsparcia). Nie można również wykluczyć konieczności przeprowadzenia dowodu z opinii biegłego.

W analizowanej sprawie nie chodzi zatem o sytuacje, w których w związku ze sprawowaniem nieodpłatnej opieki przez członka rodziny zmniejsza się dochód rodziny, ale o przypadki, w których - zdaniem SN - uzasadniona jest „wycena” wartości owej opieki i pomocy. Koresponduje to w pewnym sensie z pogladem Rzecznika Finansowego, który we wniosku o podjęcie uchwały przez SN wskazał, że wręcz „typowe” jest, że poszkodowany preferuje, zwłaszcza znajdując się w warunkach domowych, aby opiekę sprawowali najbliżsi, a nie osoba obca. Trudno więc dziwić się bliskim poszkodowanego, że czują potrzebę udzielenia mu pomocy i wsparcia psychicznego i w tym celu rezygnują z innych zajęć (niekoniecznie przecież o charakterze zarobkowym) czy swojego czasu wolnego (po pracy, w czasie urlopu, weekendu). Zdaniem Rzecznika, podobnie jak to interpretuje się w przypadku doznania szkody na mieniu (np. uszkodzenia pojazdu wskutek wypadku komunikacyjnego], obowiązek naprawienia szkody powstaje już z chwilą wyrządzenia szkody, niezależnie od tego, czy poszkodowany dokonał już naprawy, czy zrobił to samodzielnie, czy zlecając to profesjonaliście, a także - czy w ogóle zamierza dokonać naprawy w przyszłości²8. Można więc twierdzić, że w przypadku doznania szkody na osobie bezpłatna pomoc świadczona przez osoby trzecie przedstawia pewną wartość, a uszczerbek ten powinien - zdaniem Rzecznika - podlegać kompensacji w oparciu o art. 444 § 1 k.c. Skoro zatem np. samodzielna naprawa rzeczy nie zmniejsza należnego poszkodowanemu odszkodowania, to korzystanie z nieodpłatnej pomocy osób trzecich w celu poprawy stanu zdrowia czy rekonwalescencji również nie powinno pozbawiać poszkodowanego prawa dochodzenia roszczenia.

Nie negując tak ogólnie sformułowanej przez Rzecznika Finansowego i Sąd Najwyższy tezy, należy odnieść się także do wskazywanej przez te podmioty oraz w wielu orzeczeniach istniejącej opozycji odszkodowania przewidzianego w art. $444 \S 1$ k.c. oraz renty z tytułu zwiększonych potrzeb z art. 444 § 2 k.c. Rzeczywiście, w wielu przypadkach może być tak, że poszkodowanemu należy się zwrot kosztów związanych z leczeniem, rehabilitacją, nabyciem niezbędnego sprzętu czy nawet remontem mieszkania, natomiast renta stanowi niejako „kontynuację” tego odszkodowania w tym sensie, że wraz z ustabilizowaniem się sytuacji zdrowotnej poszkodowanego, który doznał pewnych trwałych następstw (choć nie zawsze nieodwracalnych), konieczne jest pokrycie jego zwiększonych potrzeb poprzez wypłatę świadczeń okresowych. Dzięki temu możliwa jest kompensacja szkody przyszłej, która obejmuje choćby koszty dalszych wizyt lekarskich, rehabilitacji, pomocy w czynnościach życia codziennego itd. W przypadku natomiast sprawowania nieodpłatnie opieki przez osoby trzecie (niekoniecznie nota bene będące członkami rodziny w sensie formalnym, może przecież chodzić o pomoc ze strony konkubenta, przyjaciółki poszkodowanego, sasiadów) wartość tego typu czynności wymyka się tradycyjnemu rozumieniu pojęcia szkody (tym bardziej, że przecież sam fakt nieporadności, bycia zdanym na pomoc osób trzecich jest powszechnie uznawany także za element krzywdy podlegającej wynagrodzeniu w oparciu o art. $445 \S 1$ k.c. ${ }^{29}$ ).

Tymczasem w związku z poświęcaniem własnego czasu na sprawowanie opieki nad poszkodowanym, co jednocześnie nie powoduje konkretnego uszczerbku majątkowego (np. w postaci zmniejszonych zarobków, dochodów osiaganych z działalności zawodowej czy gospodarczej], można się

28. Tak też wyrok SN z 8.03.2018 r., sygn. II CNP 32/17.

29. Zob. M. Wałachowska, [w:] Kodeks cywilny. Komentarz. Tom III. Zobowiqzania. Część ogólna (art. 353-534], [red.] M. Habdas, M. Fras, Wolters Kluwer, Warszawa 2018, s. 645 i nast. i cytowane tam orzecznictwo. 
zastanawiać, czy w istocie w majątku poszkodowanego w ogóle dochodzi do wyrządzenia uszczerbku. Na pierwszy rzut oka tak nie jest (skoro on osobiście nie ponosi żadnych wydatków), niemniej argument ten sam w sobie nie może przemawiać za niemożnością dochodzenia odszkodowania. Przecież nie budzi wạtpliwości w doktrynie czy orzecznictwie, że w ramach „wszelkich kosztów” wynikłych z uszkodzenia ciała lub wywołania rozstroju zdrowia mogą się mieścić koszty dojazdu osób bliskich w celu odwiedzin poszkodowanego (zwłaszcza gdy jest on małoletni) ${ }^{30}$, zatem argument o braku uszczerbku w majątku poszkodowanego jest nieoperatywny. Z drugiej strony natomiast, nie bez racji Rzecznik Finansowy zaznaczył we wniosku o wydanie uchwały, powołując się na dane GUS-u, że czas jest często „towarem bardziej deficytowym niż pieniądze, a jego wykorzystanie rzutuje na wiele dziedzin życia rodzinnego, osobistego i zawodowego". Zatem zaangażowanie osób bliskich nie może być uznane za mające na celu zmniejszenie obowiązku odszkodowawczego, ale powinno mieć określoną wartość majątkową, objętą odszkodowaniem za koszty wynikłe z doznania szkody na osobie.

Nie powinno moim zdaniem budzić watpliwości, że sam fakt powstania konieczności korzystania z opieki i pomocy osób trzecich jest uszczerbkiem wynikłym z uszkodzenia ciała lub wywołania rozstroju zdrowia. Uzasadniona wydaje się zatem sama możliwość żądania kompensacji z tego tytułu. Istotne natomiast jest, tak z teoretycznego, jak i praktycznego punktu widzenia, nie tylko to, w jaki sposób zostanie oszacowana „wartość” opieki sprawowanej nieodpłatnie, ale przede wszystkim, jaki jest charakter tego uszczerbku (majątkowy lub niemajątkowy). Konsekwencja odpowiedzi na to zasadnicze pytanie jest to, czy uszczerbek ten zaliczymy do „wszelkich kosztów” (art. $444 \S$ 1 k.c.), czy uznamy za podstawę renty z tytułu zwiększonych potrzeb (art. 444 § 2 k.c.), a nawet uwzględnimy przy szacowaniu zadośćuczynienia pieniężnego (art. 445 § 1 k.c.). Rozstrzygnięcie tych zagadnień ma nie tylko wpływ na ocenę przesłanek dochodzenia roszczeń, ale także na sposób liczenia terminów ich przedawnienia. Ponadto, jeśli uznać, jak to czynią niektóre sądy, że mamy do czynienia z roszczeniem o rentę, możliwe byłoby in casu sięgnięcie do art. 907 § 2 k.c. (zmiana wysokości i czasu trwania renty). Niewatpliwie fakt, że poszkodowany zmuszony jest korzystać z pomocy osób trzecich, co samo w sobie wiąże się dla niego z rozmaitymi niedogodnościami, także natury psychicznej, powinien być uwzględniany przy szacowaniu odpowiedniego zadośćuczynienia pieniężnego. Ponadto sądzę, że w danych okolicznościach w pojęciu wszelkich kosztów może mieścić się koszt opieki sprawowanej przez współmałżonka czy partnera życiowego poszkodowanego ${ }^{31}$ (a więc oprócz np. utraconych przez tę osobę zarobków). Wartość nakładu pracy takiej osoby trzeciej powinna być ustalana na podstawie cen rynkowych, funkcjonujących na rynku lokalnym ${ }^{32}$, zaś przykładowo specyficzne potrzeby (np. większa potrzeba obecności osób bliskich w związku z doznaniem traumy powypadkowej) czy szczególna sytuacja poszkodowanego (np. konieczność zaprzestania uprawiania sportu zawodowego] powinny mieć moim zdaniem wpływ na wymiar zadośćuczynienia. Fakt, że osoba trzecia nie porzuca pracy zarobkowej czy nie ogranicza działalności gospodarczej, nie oznacza przecież, że nie można „wycenić” wartości wykonywanych przez nią czynności. Podobnie zresztą można przyjąć, gdy chodzi np. o rentę z tytułu niezdolności do pracy dla osoby, która nie pracowała w dniu wypadku, ale wartość pracy, którą musi „za nią” wykonać osoba trzecia (np. w zakresie prowadzenia domu, opieki na dziećmi], może być realnie oszacowana.

30. Zob. wyrok SN z 7.10.1971 r., sygn. II CR 427/71, „Orzecznictwo Sądów Polskich” 1972, nr 6, poz. 108; M. Wałachowska, op. cit., s. 624; W. Czachórski, op. cit., s. 663.

31. Zob. też M. Wałachowska, op. cit., s. 625.

32. Ibidem, s. 630. 
Takie ujęcie pozwala jednocześnie na realizację zasady pełnego odszkodowania, która może być ujmowana w omawianych stanach faktycznych jako dążenie do przywrócenia zaburzenia równowagi w sferze prawno-majątkowej poszkodowanego, w granicach adekwatnego związku przyczynowego ${ }^{33}$. W przypadku szkody na osobie jest to często możliwe jedynie przez zasądzenie odpowiedniej sumy pieniężnej. Ponadto, zasądzona kwota nie może prowadzić do nieusprawiedliwionego wzbogacenia poszkodowanego. Sạd powinien zatem uwzględnić także korzyści płynące ze zdarzenia szkodzącego, które moga polegać na powiększeniu majątku lub zaoszczędzeniu wydatków, które poszkodowany poniósłby, gdyby nie zdarzenie wyrządzające szkodę ${ }^{34}$ (compensatio lucri cum damno). W tym kontekście można się zastanawiać, czy nieodpłatna pomoc świadczona przez osoby trzecie nie jest właśnie taką korzyścią po stronie poszkodowanego (zaoszczędzenie wydatków na odpłatną pomoc). Ponieważ jest to pomoc świadczona co do zasady dobrowolnie, nie zmniejsza ona obowiązku odszkodowawczego ${ }^{35}$. Co więcej, żądane koszty muszą pozostawać w adekwatnym związku przyczynowym, który pełni dwojaką funkcję: z jednej strony jest przesłanką obowiazku odszkodowawczego, a z drugiej - pozwala ograniczyć zakres tego obowiązku tylko do normalnych następstw zdarzenia powodującego odpowiedzialność (sprawcy lub innego podmiotu, a więc np. osób zobowiązanych do nadzoru, pracodawcy czy ubezpieczyciela tych podmiotów).

Jak wspomniano, koszty te muszą być niezbędne i celowe, a więc niekoniecznie związane z korzystaniem z systemu instytucjonalnego opieki finansowanej ze środków publicznych. Celowość powinna być rozumiana w ten sposób, że potrzeba np. korzystania z pomocy osoby trzeciej musi być związana z charakterem uszczerbku na zdrowiu, stanem zdrowotnym poszkodowanego i jego indywidualna sytuacją (a więc także brakiem dostępności profesjonalnej opieki w miejscu zamieszkania). Zgadzając się zatem z ogólną tezą głosowanej uchwały, można wskazać, że co do istoty sama potrzeba korzystania z opieki nieodpłatnej mieści się w pojęciu kosztów wynikłych z doznania szkody na osobie, możliwe jest ponadto określenie wymiernej wartości tej opieki. Fakt ten jednocześnie może być podstawą wynagrodzenia szkody przyszłej poprzez przyznanie renty z tytułu zwiększonych potrzeb (art. 444 § 2 k.c.) oraz ma znaczenie przy szacowaniu zadośćuczynienia pieniężnego za doznaną krzywdę (art. 445 § 1 k.c.).

\section{Wykaz źródeł}

Bagińska E., [w:] System Prawa Medycznego. Tom 5. Odpowiedzialność prywatnoprawna, Bagińska E. [red.], CH Beck, Warszawa 2021.

Czachórski W., [w:] System Prawa Cywilnego. Tom III. Część 1. Prawo zobowiqzań - część ogólna, Radwański Z. [red.], Ossolineum, Wrocław 1981.

33. Zob. E. Bagińska, op. cit., s. 689.

34. Zob. np. wyrok SN z 5.03.2009 r., sygn. III CSK 283/08; uchwała SN z 15.05.2009 r., sygn. III CZP 140/08 (zasada prawna).

35. Taka sama argumentacja dotyczyłaby np. przypadku, gdyby opiekę sprawowali rodzice sprawujący władzę rodzicielską - opieka nad poszkodowanym wykracza, moim zdaniem, poza zakres obowiązku alimentacyjnego, zatem czynności z tym związane są „dodatkowe” i konieczność ich wykonywania jest skutkiem wyrządzenia szkody na osobie czynem niedozwolonym. 
Hadrowicz S., Nieodpłatna opieka jako koszt w świetle art. 444 § 1 k.c., „Studia Prawa Prywatnego” 2021, $\mathrm{nr} 2$.

Hadrowicz S., Koszty „nieodpłatnej” opieki a pojęcia szkody podlegajqcej kompensacji na podstawie art. 444 § 1 k.c. Glosa do uchwały składu siedmiu sędziów Sqdu Najwyższego - Izba Cywilna z dnia 22 lipca 2020 r., III CZP 31/19, „Orzecznictwo Sądów Polskich” 2021, nr 6.

Kaliński M., Szkoda na mieniu i jej naprawienie, CH Beck, Warszawa 2014.

Kaliński M., Szkoda na osobie i jej naprawienie, CH Beck, Warszawa 2021.

Machnikowski P., Śmieja A., [w:] System Prawa Prywatnego. Tom 6. Prawo zobowiqzań - część ogólna, Olejniczak A. [red.], CH Beck, Warszawa 2018.

Misztal-Konecka J., Kilka uwag o kosztach opieki nad poszkodowanym jako szkodzie podlegajacej naprawieniu na podstawie art. 444 § 1 zd. 1 k.c. [w:] lus est iustitia appelatum. Księga jubileuszowa dedykowana Profesorowi Tadeuszowi Wiśniewskiemu, red. T. Ereciński, J. Gudowski, M. Pazdan, M. Tomalak, Wolters Kluwer, Warszawa 2017.

Safjan M., [w:] Kodeks cywilny. Tom I. Komentarz. Art. 1-449(10), Pietrzykowski K., CH Beck, Warszawa 2015.

Sobolewski P., [w:] Kodeks cywilny. Komentarz, Osajda K. [red.], CH Beck, Warszawa 2021.

Strugała R., Dobra i interesy chronione w strukturze czynu niedozwolonego, CH Beck, Warszawa 2019. Wałachowska M., [w:] Kodeks cywilny. Komentarz. Tom III. Zobowiqzania. Część ogólna (art. 353534], Habdas M., Fras M., Wolters Kluwer, Warszawa 2018.

\section{Costs of unpaid care for the injured person and the scope of the insurer's liability for personal injury. Some thoughts on the 7 judges of the Supreme Court resolution of 22 July 2020 (III CZP 31/19)}

This study analyzes the resolution of the Supreme Court, according to which the costs of unpaid care performed for an injured person fall within the concept of costs resulting from sustaining personal injury. The author presents various judgments of courts and the views presented by the civil law doctrine, pointing out that the view of the Supreme Court can, in principle, be accepted. She adds that there are also arguments that the necessity to use third party assistance may be considered in a specific case not only as a pecuniary damage, but also as a factor taken into account when estimating damages for non-pecuniary loss.

Keywords: personal injury, medical expenses, free care, damages, compensation for non-pecuniary loss.

DR. HAB. MONIKA WAŁACHOWSKA - profesor Uniwersytetu Mikołaja Kopernika w Toruniu, Kierownik Katedry Prawa Ubezpieczeniowego i Medycznego na Wydziale Prawa i Administracji UMK e-mail: walachowska@umk.pl

ORCID: 0000-0002-4930-0595 